\title{
The post-endocytotic fate of the gonadotropin receptors is an important determinant of the desensitization of gonadotropin responses
}

\author{
R S Bhaskaran and M Ascoli \\ Department of Pharmacology, Carver College of Medicine, 2-319B BSB, 51 Newton Road, University of lowa, lowa City, lowa 52242-1109, USA \\ (Requests for offprints should be addressed to M Ascoli; Email: mario-ascoli@uiowa.edu)
}

\begin{abstract}
Internalization of the ligand/receptor complexes is a consequence of the activation of the gonadotropin receptors. Since the recycling or degradation of the internalized receptors results in the maintenance or loss of cell surface receptors respectively and this contributes to the loss of responsiveness, we hypothesized that the fate of the internalized receptors could be an important component of desensitization. We examined this hypothesis using the wild-type and mutants of the human LH (hLHR) receptors and follitropin receptors expressed in MA-10 and KK-1 cells respectively. The receptor mutants were chosen because they are routed mostly to a lysosomal degradation pathway whereas the wild-type receptors are recycled back to the surface. We have shown that agonist stimulation of cells expressing the mutant receptors results in a more pronounced loss of cell surface receptors and agonist responses than stimulation of cells expressing the wild-type receptors. We concluded that receptor recycling promotes the maintenance of cell surface receptors and preserves hormonal responsiveness. This property of the hLHR is likely to be physiologically important because there at least two hLHR-expressing tissues in pregnant women, the maternal corpus luteum and the fetal Leydig cells, where a loss of hormonal responsiveness induced by the elevated levels of human chorionic gonadotropin that occur during pregnancy is not desirable.
\end{abstract}

Journal of Molecular Endocrinology (2005) 34, 447-457

\section{Introduction}

The desensitization of lutropin $(\mathrm{LH}) /$ chorionic gonadotropin (CG)-induced responses has been studied in some detail in rodent granulosa and Leydig cells. Some of the hormone-induced effects that contribute to this phenomenon include: (a) an impairment in the functional properties of the cell surface LH receptor (LHR) that results in a decrease in adenylyl cyclase activation (Ekstrom \& Hunzicker-Dunn 1989, Sánchez-Yagüe et al. 1993, Lamm \& Hunzicker-Dunn 1994, Ascoli 1996, Wang et al. 1997, Mukherjee et al. 1999, HunzickerDunn et al. 2002); (b) the down-regulation of cell surface receptors (Freeman \& Ascoli 1981, Wang et al. 1991); (c) a decrease in cholesterol availability (Quinn et al. 1981, Freeman \& Ascoli 1982); and (d) a decrease in the levels and/or activity of some of the steroidogenic enzymes such as 17a-hydroxylase (Catt et al. 1980, Nozu et al. 1981).

The LH/CG-induced down-regulation of the cell surface LHR can be due to a decrease in the synthesis and/or an increase in the degradation of the LHR. In the MA-10 cells, we have shown that LH/CG-induced internalization and subsequent lysosomal degradation of the endogenous mouse LHR is the most important contributor to down-regulation (Wang et al. 1991). LH/CG-induced changes in the synthesis of the LHR also occur. These are secondary to a cAMP-mediated decrease in the LHR mRNA but they are quantitatively unimportant to the overall process of receptor down-regulation (Wang et al. 1991, 1992).

During the past several years we (Ascoli 1984, Baratti-Elbaz et al. 1999, Kishi \& Ascoli 2000, Kishi et al. 2001, Galet et al. 2003, 2004, Hirakawa et al. 2003, Krishnamurthy et al. 2003) and others (Ghinea et al. 1992, Beau et al. 1997, 1998, Baratti-Elbaz et al. 1999) have elucidated several features of the post-endocytotic trafficking of the porcine (p), rat (r), mouse $(\mathrm{m})$ and human (h) LHR and follitropin receptors (FSHR). Most of the internalized $\mathrm{hGG} / \mathrm{rLHR}, \mathrm{hGG} / \mathrm{mLHR}$ or hGG/pLHR complexes are routed to the lysosomes where the hormone and the receptor are degraded (Ascoli 1984, Ghinea et al. 1992, Baratti-Elbaz et al. 1999, Kishi et al. 2001). In contrast, most of the internalized $\mathrm{hFSH} / \mathrm{rFSHR}$ or $\mathrm{hFSH} / \mathrm{hFSHR}$ complexes accumulate in endosomes and subsequently recycle back to the cell surface where the bound, intact hFSH dissociates back into the medium and can bind to the receptor again (Krishnamurthy et al. 2003). The fate of the hGG/hLHR complex appears to be intermediate 
between the fates of the complexes described above. In this case, there is little accumulation of the internalized hLHR in the lysosomes and there is a fairly even distribution in the amounts of internalized hCG that are released back into the medium in degraded and undegraded forms (Kishi et al. 2001, Galet et al. 2003, 2004, Hirakawa et al. 2003).

Since the recycling or degradation of the internalized gonadotropin receptors results in the maintenance or loss of cell surface receptors respectively (Wang et al. 1991, Kishi et al. 2000, 2001, Galet et al. 2003, 2004, Hirakawa et al. 2003, Krishnamurthy et al. 2003) and the loss of cell surface receptors contributes to desensitization (Wang et al. 1991), we hypothesized that the intracellular fate of the internalized receptors should be an important component of desensitization. The differential post-endocytotic fate of the rLHR and the hLHR (see above) could be a functionally important property of the hLHR because there at least two LHR-expressing tissues in pregnant women, the maternal corpus luteum and the fetal Leydig cells, where a loss of hormonal responsiveness induced by the elevated levels of hCG that occur during pregnancy is not desirable.

The experiments presented here were designed to test this hypothesis by examining the hormone-induced loss of cell surface receptors and responsiveness in target cells transiently transfected with the wild-type hLHR and hFSHR as well as in target cells expressing mutants of the hLHR and hFSHR that are targeted to a degradation pathway.

\section{Materials and methods}

\section{Plasmids and cells}

The preparation and characterization of expression vectors for the myc-hLHR-wt, myc-hLHR-t682, myc-hFSHR-wt and myc-hFSHR-t678 have been described (Min \& Ascoli 2000, Hirakawa et al. 2003, Krishnamurthy et al. 2003). The origin, handling and methods used for transfection of MA-10 cells have been described (Ascoli 1981, Hirakawa et al. 2002, Hirakawa \& Ascoli 2003a). The only change made is that the cells are now maintained in RPMI-1640 instead of Waymouth's MB752/1. (This change was prompted by the fact that most suppliers are no longer offering Waymouth's MB752/l.) A transformed mouse granulosa cell line (designated KK-1, see Rahman \& Huhtaniemi 2001) was provided by Dr I Huhtaniemi (Imperial College, London, UK). KK-1 cells were maintained in Dulbecco's modified Eagles' medium modified to contain $10 \mathrm{mM}$ Hepes, 10\% newborn calf serum and $50 \mu \mathrm{g} / \mathrm{ml}$ gentamicin. These cells were transfected using the same procedures as those used for

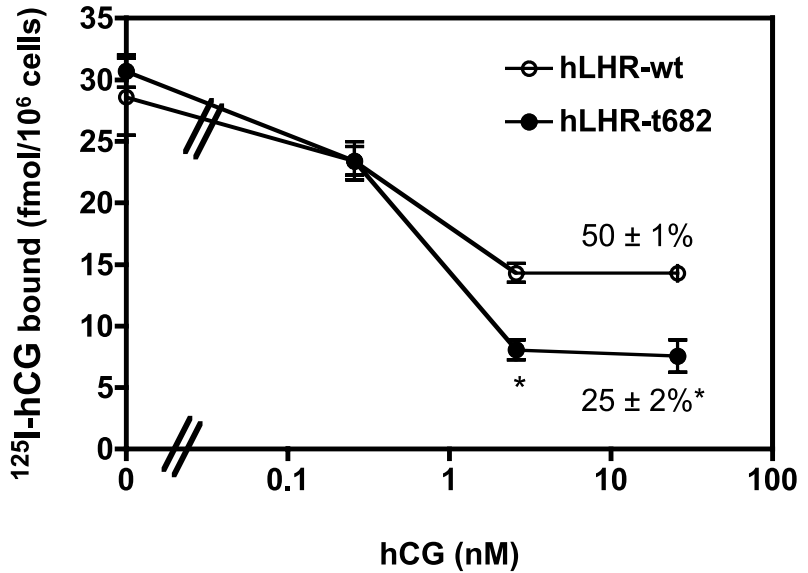

Figure 1 The hCG-induced loss of cell surface hLHR is more pronounced in MA-10 cells expressing the hLHR-t682 than in MA-10 cells expressing the hLHR-wt. MA-10 cells transiently transfected with the hLHR-wt or hLHR-t682 were incubated with the indicated concentrations of hCG for $16 \mathrm{~h}$ at $37^{\circ} \mathrm{C}$. The cells were then washed with a neutral and an acidic buffer to remove the free and bound hCG and then they were used to measure residual ${ }^{125}$ I-hCG binding during an overnight incubation at $4{ }^{\circ} \mathrm{C}$ as described in Materials and methods. Each point shows the mean \pm S.E.M. of three to five independent transfections. The asterisks indicate a statistically significant difference ( $t$-test, $P \leq 0.05$ ) between the two groups of cells. The numbers above the last point depict ${ }^{125}$ /-hCG binding as $\%$ of that detected in the cells incubated without hCG.

MA-10 cells (Hirakawa et al. 2002, Hirakawa \& Ascoli 2003a).

\section{Binding assays}

Transiently transfected cell monolayers (in $35 \mathrm{~mm}$ wells) were washed and placed in $1 \mathrm{ml}$ assay medium (RPMI-1640 containing $20 \mathrm{mM}$ Hepes, $50 \mu \mathrm{g} / \mathrm{ml}$ gentamicin and $1 \mathrm{mg} / \mathrm{ml}$ bovine serum albumin (BSA), $\mathrm{pH} \mathrm{7 \cdot 4)}$ and incubated for $16 \mathrm{~h}$ in the absence or presence of hFSH or hCG $(30 \mathrm{nM})$. At the end of this incubation the cells were placed on ice and washed two to three times with $2 \mathrm{ml}$ portions of cold wash medium (Hank's balanced salt solution containing $1 \mathrm{mg} / \mathrm{ml}$ BSA). The surface-bound hormone was then released by incubating the cells in $1 \mathrm{ml}$ cold $50 \mathrm{mM}$ glycine, $150 \mathrm{mM} \mathrm{NaCl}, \mathrm{pH} 3$ for $2-4 \mathrm{~min}$ (Ascoli 1982). This buffer was removed and the cells were washed once more with the same acidic buffer and then once with cold assay medium. The cells were then put back in $1 \mathrm{ml}$ warm assay medium and incubated with ${ }^{125} \mathrm{I}$-hCG or ${ }^{125} \mathrm{I}$-hFSH $(3 \mathrm{nM})$ overnight at $4{ }^{\circ} \mathrm{C}$. At the end of this incubation the cells were washed three to four times (using cold Hank's balanced salt solution supplemented with $1 \mathrm{mg} / \mathrm{ml} \mathrm{BSA).} \mathrm{After} \mathrm{aspiration} \mathrm{of} \mathrm{the} \mathrm{last} \mathrm{wash,}$ the cells were dissolved in $50 \mu \mathrm{l} 1 \mathrm{M} \mathrm{NaOH}$, collected 


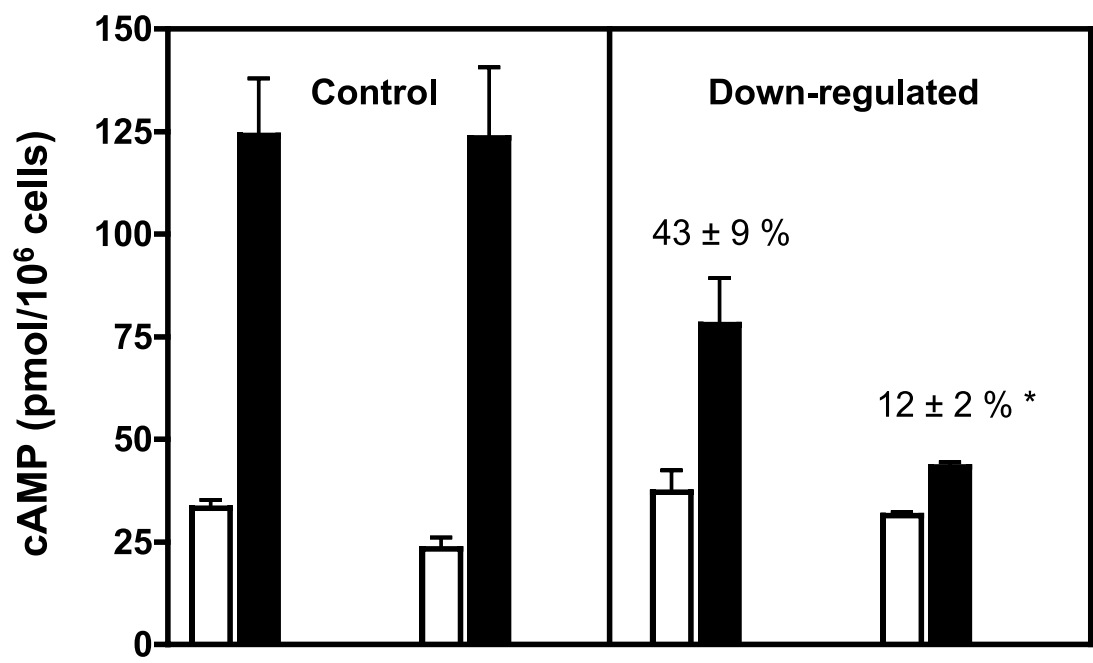

\section{hLHR-wt hLHR-t682 hLHR-wt hLHR-t682}

Figure 2 The hCG-induced loss of cAMP responses is more pronounced in MA-10 cells expressing the hLHR-t682 than in MA-10 cells expressing the hLHR-wt. MA-10 cells transiently transfected with the hLHR-wt or hLHR-t682 were incubated with $30 \mathrm{nM}$ hCG for $16 \mathrm{~h}$ at $37^{\circ} \mathrm{C}$. The cells were then washed with a neutral and an acidic buffer to remove the free and bound hCG and then incubated without (open bars) or with $0.3 \mathrm{nM} \mathrm{hCG}$ (solid bars) for 30 min prior to the measurement of intracellular cAMP. Each bar shows the mean \pm S.E.M. of three to five independent transfections. The numbers above the bars of the down-regulated cells display the hCG-induced cAMP response expressed as \% of the response of the control cells expressing the same receptor. This was calculated after subtraction of the basal from the stimulated levels of CAMP in the control and down-regulated cells. The asterisk indicates a statistically significant difference ( $t$-test, $P \leq 0 \cdot 05$ ) between the two groups of down-regulated cells.

with a cotton swab and counted in a gamma counter. Three wells were used for each binding assay. Two of them received ${ }^{125} \mathrm{I}-\mathrm{hCG}$ only but the third one also received $500 \mathrm{ng} / \mathrm{ml}$ crude $\mathrm{hCG}$ or $500 \mathrm{ng} / \mathrm{ml}$ equine FSH. This last well was used to correct for non-specific binding.

\section{Cyclic AMP and progesterone assays}

Transfected cell monolayers were incubated with or without gonadotropins for $16 \mathrm{~h}$ as described above. After removal of the surface-bound hormone (see above) the cells were put back in warm assay medium and incubated with or without hormone for $30 \mathrm{~min}$ (for cAMP assays) or $4 \mathrm{~h}$ (for progesterone assays) at $37^{\circ} \mathrm{C}$. Intracellular cAMP and extracellular progesterone were measured as described earlier (Segaloff et al. 1981, Hirakawa et al. 2002).

\section{Hormones and supplies}

Purified hCG (AFP8456A) was purchased from Dr A Parlow of the National Hormone and Pituitary Agency, Bethesda, MD, USA. Recombinant hFSH was kindly provided by the Serono Reproductive Biology Institute (Rockland, MA, USA). ${ }^{125} \mathrm{I}-\mathrm{hCG}$ and ${ }^{125} \mathrm{I}-\mathrm{hFSH}$ were prepared as described elsewhere (Ascoli \& Puett 1978). Cell culture supplies and reagents were obtained from Corning (Rochester, NY, USA) and Invitrogen (Carlsbad, CA, USA) respectively. All other chemicals were obtained from Sigma or Fisher Scientific (Pittsburgh, PA, USA). Radiochemicals were from Amersham.

\section{Results}

\section{Down-regulation of the hLHR and hCG-mediated responses in transfected MA-10 cells}

To assess the importance of receptor down-regulation on hCG responsiveness, we transiently expressed the hLHR-wt or an hLHR mutant truncated at residue 682 of the C-terminal tail (designated hLHR-t682) in MA-10 cells. Although MA-10 cells express endogenous mLHR, the expression of the transfected hLHR (or mutants thereof) is several orders of magnitude higher and, therefore, the functional properties of the transfected hLHR (or mutant thereof) can be readily examined 


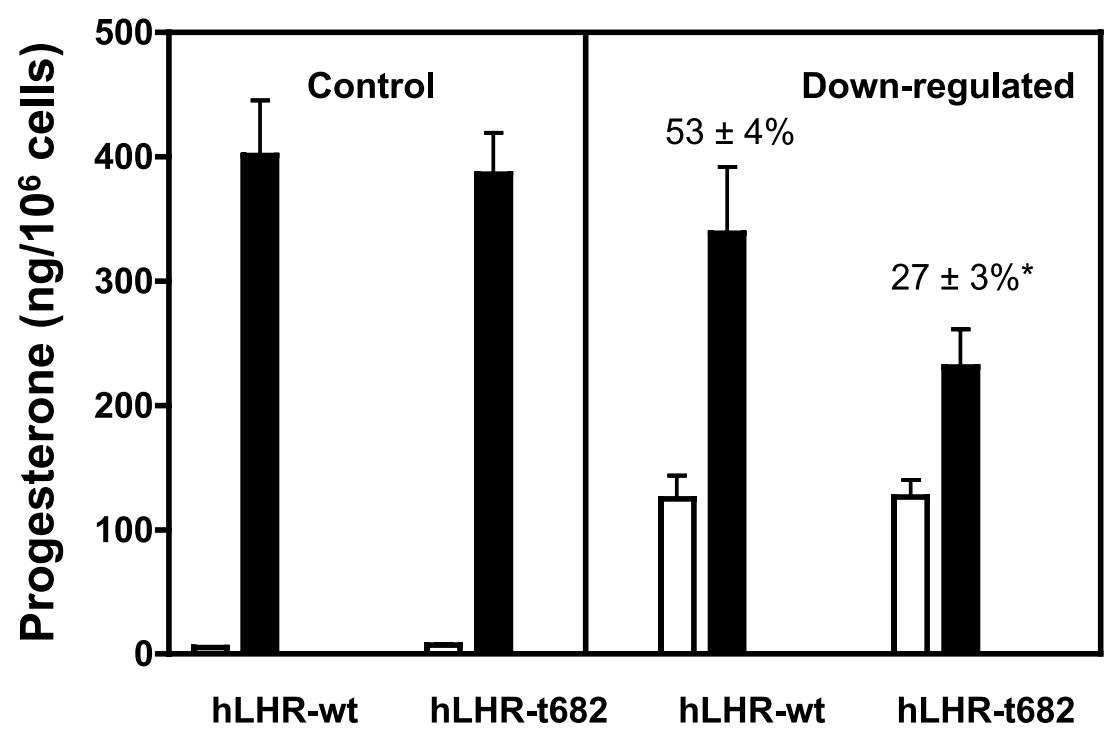

Figure 3 The hCG-induced loss of progesterone responses is more pronounced in MA-10 cells expressing the hLHR-t682 than in MA-10 cells expressing the hLHR-wt. MA-10 cells transiently transfected with the hLHR-wt or hLHR-t682 were incubated with $30 \mathrm{nM} \mathrm{hCG}$ for $16 \mathrm{~h}$ at $37^{\circ} \mathrm{C}$. The cells were then washed with a neutral and an acidic buffer to remove the free and bound hCG and then incubated without (open bars) or with $0.03 \mathrm{nM} \mathrm{hCG}$ (solid bars) for $4 \mathrm{~h}$ prior to the measurement of progesterone. Each bar shows the mean \pm S.E.M. of three to five independent transfections. The numbers above the bars of the down-regulated cells display the hCG-induced progesterone response expressed as \% of the response of the control cells expressing the same receptor. This was calculated after subtraction of the basal from the stimulated levels of progesterone in the control and down-regulated cells. The asterisk indicates a statistically significant difference ( $t$-test, $P \leq 0.05)$ between the two groups of down-regulated cells.

against a low background of endogenous mLHR (Hirakawa et al. 2002).

Figure 1 shows that MA-10 cells transfected with the hLHR-wt or hLHR-t682 bind similar levels of ${ }^{125} \mathrm{I}$-hCG. Cells expressing either of these two receptors were incubated with increasing concentrations of hCG for $16 \mathrm{~h}$ at $37^{\circ} \mathrm{C}$, the free and surface-bound hormone were removed by washing the cells under neutral and acidic conditions respectively, and the residual cell surface receptors were measured using ${ }^{125} \mathrm{I}-\mathrm{hCG}$ (Segaloff \& Ascoli 1981, Ascoli 1982). The results presented in Fig. 1 show that at optimally effective concentrations of hCG $(3-30 \mathrm{nM})$ there was a $\sim 50 \%$ and $\sim 75 \%$ loss respectively of surface receptors in cells expressing hLHR-wt or hLHR-t682. This difference in the hormone-induced loss of cell surface receptors has been previously described in a heterologous cell type (Hirakawa et al. 2003, Galet et al. 2004) and it is a reflection of the differential post-endocytotic fate of the hLHR-wt and hLHR-t682. Whereas roughly half of the internalized hCG/hLHR-wt complex is recycled back to the plasma membrane less that $10 \%$ of the internalized hCG/hLHR-t682 is recycled (Kishi et al. 2001, Galet et al. 2003, 2004, Hirakawa et al. 2003). The majority of the hCG/hLHR-t682 complex is instead routed to a lysosomal degradation pathway where the hormone and the receptor are degraded (Kishi et al. 2001, Galet et al. 2003, 2004, Hirakawa et al. 2003).

To determine if these changes in receptor density have a differential effect on hCG responsiveness, MA-10 cells expressing the hLHR-wt or hLHR-t682 were incubated without or with $30 \mathrm{nM} \mathrm{hCG}$ for $16 \mathrm{~h}$ and the free and bound hormone were removed as described above. The control (i.e. cells treated without hCG) or down-regulated cells (i.e. cells treated with hCG) were then tested for their ability to respond with cAMP and progesterone accumulation to a new hCG challenge.

Transiently transfected MA-10 cells have a large complement of spare hLHR and the concentrationresponse curves for binding, cAMP and progesterone accumulation are characterized by $\mathrm{EC}_{50}$ values of $\sim 1$, $\sim 0.1 \mathrm{nM}$ and $\sim 0.03 \mathrm{nM}$ respectively (Hirakawa et al. 2002). In this respect, the transiently transfected MA-10 cells resemble normal Leydig cells where steroid accumulation is maximal at low levels of receptor occupancy and cAMP accumulation (Mendelson et al. 1975). Therefore changes in steroid accumulation that may occur when receptor levels are reduced are more 


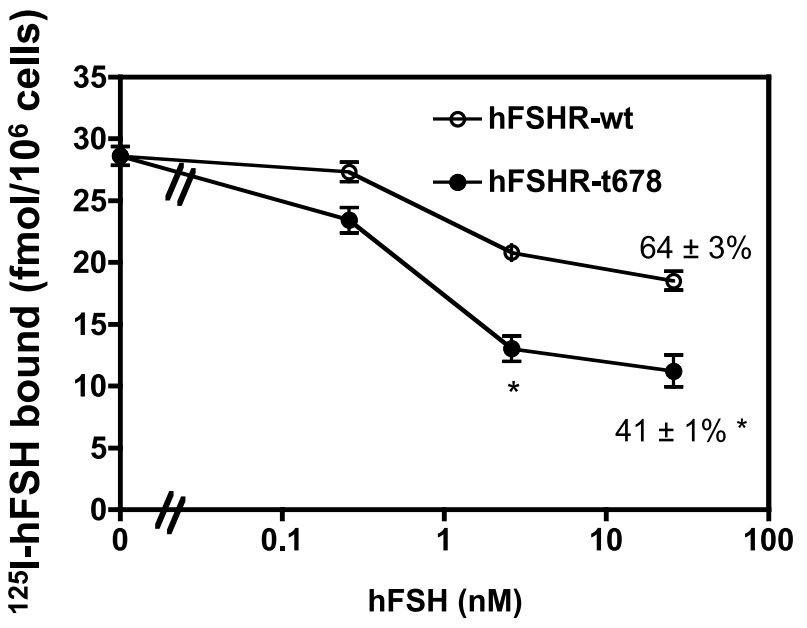

Figure 4 The hFSH-induced loss of cell surface hFSHR is more pronounced in KK-1 cells expressing the hFSHR-t678 than in KK-1 cells expressing the hFSHR-wt. KK-1 cells transiently transfected with the hFSHR-wt or hLHR-t678 were incubated with the indicated concentrations of hFSH for $16 \mathrm{~h}$ at $37^{\circ} \mathrm{C}$. The cells were then washed with a neutral and an acidic buffer to remove the free and bound $\mathrm{hFSH}$ and then they were used to measure residual ${ }^{125} \mathrm{~J}-\mathrm{hFSH}$ binding during an overnight incubation at $4^{\circ} \mathrm{C}$ as described in Materials and methods. Each point shows the mean \pm S.E.M. of three to five independent transfections. The asterisks indicate a statistically significant difference ( $t$-test, $P \leq 0.05$ ) between the two groups of cells. The numbers above the last point depict ${ }^{125}$ |-hFSH binding as \% of that detected in the cells incubated without hFSH.

likely to be detectable when cells are challenged with submaximal concentrations of hCG (Catt et al. 1979, 1980). As such, the residual responsiveness of control and down-regulated cells was measured using a nearly maximally effective concentration of hCG for cAMP accumulation (0.3 nM; Fig. 2) and a submaximal concentration of hCG for progesterone accumulation (0.03 nM; Fig. 3).

The results presented show that the residual cAMP (Fig. 2) and progesterone (Fig. 3) responses of down-regulated cells were proportional to the loss of receptors induced by pre-exposure to hCG. The left-hand panel of Fig. 2 shows that cells expressing equivalent levels of hLHR-wt or hLHR-t682 respond to an hCG challenge with a similar increase in cAMP accumulation. When these cells were pretreated overnight with hCG to induce receptor down-regulation (see right-hand panel of Fig. 2), however, the cAMP responsiveness of cells expressing the hLHR-wt (where receptor loss was only $\sim 50 \%$, cf. Fig. 1) dropped to $\sim 40 \%$ of the control cells. In contrast, the cAMP responsiveness of cells expressing the hLHR-t682 and treated overnight with hCG (where receptor loss was $\sim 75 \%$, cf. Fig. 1 ) dropped to $\sim 12 \%$ of the response of control cells.
A similar phenomenon was observed when progesterone was measured instead of cAMP (Fig. 3). The left-hand panel of Fig. 3 shows that cells expressing equivalent levels of hLHR-wt or hLHR-t682 responded to an hCG challenge with a similar increase in progesterone accumulation. When these cells were pretreated overnight with hCG to induce receptor down-regulation (see right-hand panel of Fig. 3), however, the progesterone responsiveness of cells expressing the hLHR-wt (where receptor loss was only $\sim 50 \%$, cf. Fig. 1) dropped to $\sim 50 \%$ of untreated cells. In contrast, the progesterone response of downregulated cells expressing the hLHR-t682 (where receptor loss was $\sim 75 \%$, cf. Fig. 1) dropped to $\sim 30 \%$ of the response of control cells.

In contrast to the basal levels of cAMP, which increased minimally in the down-regulated cells (compare the open bars in the two panels in Fig. 2), the basal levels of progesterone were about 20-fold higher in the downregulated cells than in the control cells (compare the open bars in the two panels in Fig. 3). This increase, which is due to the stimulation of the cells by the initial exposure to hCG, was similar in cells expressing either of the two receptors. Therefore the loss of responsiveness found in the down-regulated cells was due to a true differential decrease in the cAMP (compare the solid bars in the two panels of Fig. 2) or progesterone responses (compare the solid bars in the two panels of Fig. 3) to the new hCG challenge rather than to a differential increase in the basal levels of cAMP or progesterone induced by the previous treatment with hCG (compare the open bars in the two panels of Fig. 2 or Fig. 3).

\section{Down-regulation of the hFSHR- and hFSH-mediated responses in transfected KK-1 cells}

A similar set of experiments was then performed using a mouse granulosa cell line (KK-1 cells) transiently expressing the hFSHR-wt or a mutant truncated at residue 678 of the $\mathrm{C}$-terminal tail. Untransfected KK-1 cells express small amounts of endogenous mFSHR as judged by their ability to bind ${ }^{125} \mathrm{I}-\mathrm{hFSH}$ (data not shown). Since transient transfection of KK-1 cells with the hFSHR-wt or mutants thereof results in a five- to tenfold increase in ${ }^{125}$ I-hFSH binding (data not shown), the transfected KK-1 cells can also be used to study the functional properties of the transfected FSHR against a low background of endogenous FSHR.

We have previously shown that, when expressed in several cell types (including KK-1 cells), most of the internalized hFSH/hFSHR-wt complex is recycled back to the plasma membrane and that truncation of the hFSHR at residue 678 re-routes a substantial portion of the internalized complex to a lysosomal degradation pathway (Krishnamurthy et al. 2003). In human kidney 293 cells, this re-routing of the hFSH/hFSHR-t678 


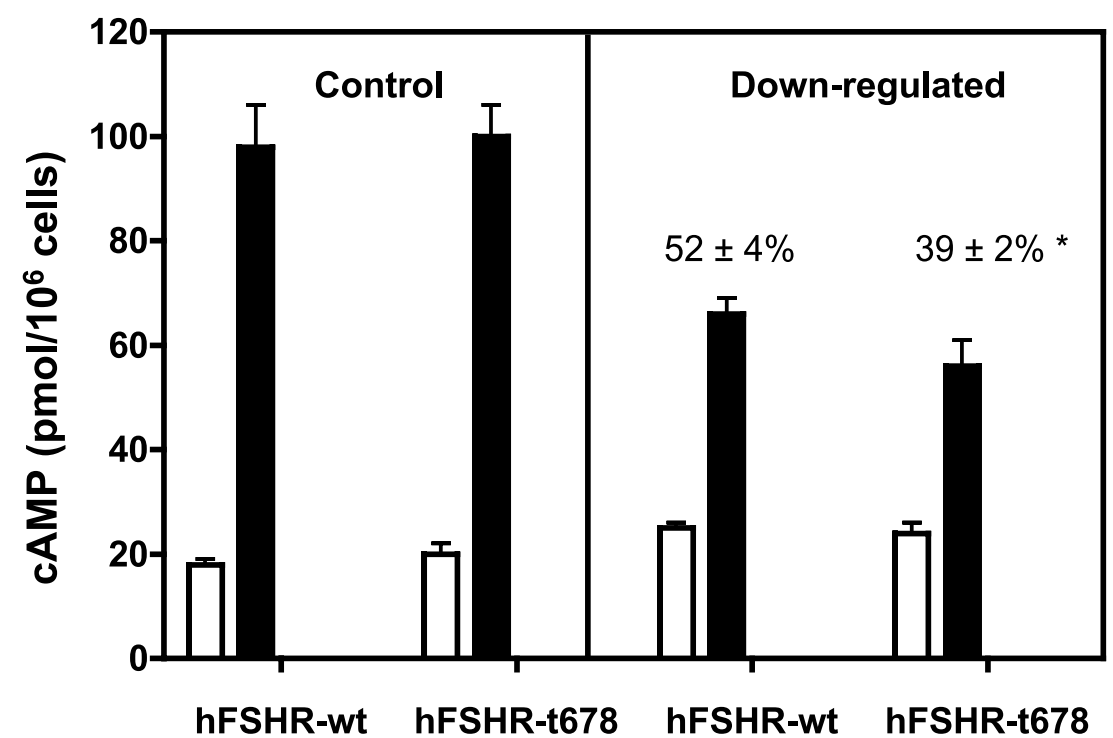

Figure 5 The hFSH-induced loss of cAMP responses is more pronounced in KK-1 cells expressing the hFSHR-t678 than in KK-1 cells expressing the hFSHR-wt. KK-1 cells transiently transfected with the hFSHR-wt or hFSHR-t678 were incubated with $30 \mathrm{nM} \mathrm{hFSH}$ for $16 \mathrm{~h}$ at $37^{\circ} \mathrm{C}$. The cells were then washed with a neutral and an acidic buffer to remove the free and bound hFSH and then incubated without (open bars) or with $0.3 \mathrm{nM} \mathrm{hFSH}$ (solid bars) for 30 min prior to the measurement of intracellular CAMP. Each bar shows the mean \pm S.E.M. of three to five independent transfections. The numbers above the bars of the down-regulated cells display the $\mathrm{hFSH}$-induced cAMP response expressed as \% of the response of the control cells expressing the same receptor. This was calculated after subtraction of the basal from the stimulated levels of cAMP in the control and down-regulated cells. The asterisk indicates a statistically significant difference $(t$-test, $P \leq 0.05)$ between the two groups of down-regulated cells.

complex results in a greater degree of down-regulation of the cell surface receptors in cells expressing hFSHR-t678 when compared with cells expressing the hFSHR-wt (Krishnamurthy et al. 2003). A similar phenomenon is demonstrated herein (Fig. 4) in transiently transfected KK-1 cells expressing these two receptors at a similar density. KK-1 cells transiently expressing the hFSHR-wt and exposed to increasing concentrations of hFSH experienced a $\sim 40 \%$ loss of cell surface receptors whereas KK-1 cells expressing hFSHR-t678 experienced a $\sim 60 \%$ loss.

The more pronounced loss of receptors observed in cells expressing the hFSHR-t678 was accompanied by a more pronounced loss of cAMP responsiveness when the cells were exposed to a second challenge with hFSH (Fig. 5). The cAMP response of down-regulated cells expressing the hFSHR-wt was $\sim 50 \%$ of the control cells whereas the cAMP response of down-regulated cells expressing the hFSHR-t678 was $\sim 40 \%$ of the control cells. Again, it is worth noting that this loss of responsiveness was due to a differential decrease in the magnitude of the cAMP response in cells re-challenged with hFSH (compare the solid bars between the rightand left-hand panels in Fig. 5) rather than to a differential changes in the basal levels of cAMP induced by the initial hFSH stimulation (compare the open bars between the right- and left-hand panels in Fig. 5). In fact, the basal levels of cAMP in the two groups of control and down-regulated cells were statistically indistinguishable.

Repeated attempts to measure an increase in estradiol levels in KK-1 cells transfected with the hFSHR-wt and incubated with hFSH and androstenedione were unsuccessful. Thus, the effects of hFSHR downregulation on hFSH-induced steroid synthesis could not be ascertained.

\section{Relationship between gonadotropin receptor density and cellular responses}

The interpretation of many of the experiments described above is based on the assumption that changes in the cAMP or progesterone responses are caused by changes in receptor density rather than changes in their downstream effectors or the metabolic pathways leading to progesterone biosynthesis.

The changes in cAMP accumulation reported here (Figs 2 and 5) could in theory be attributed to changes in 

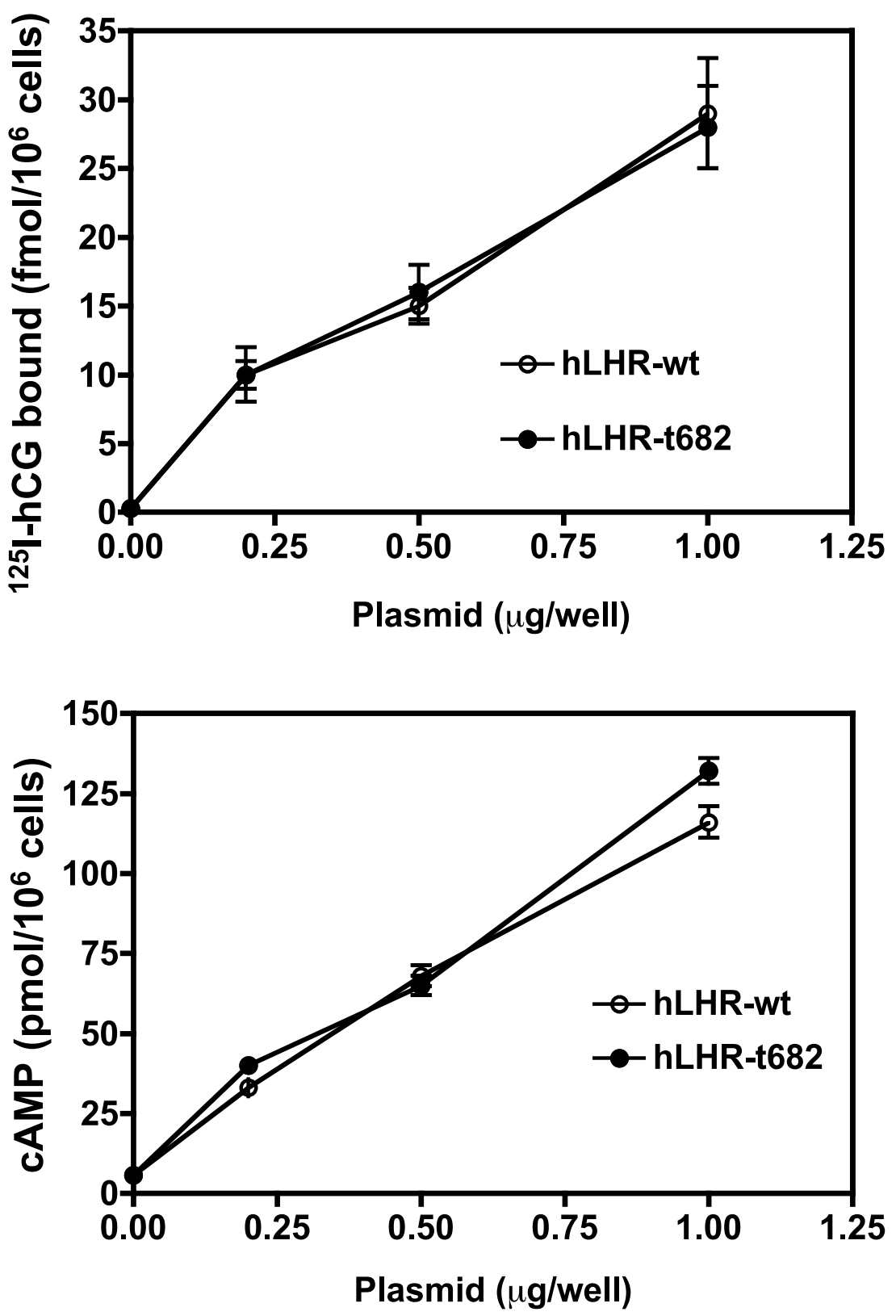

Figure 6 The hCG-induced cAMP response is proportional to LHR density in MA-10 cells transfected with the hLHR-wt or hLHR-t682. MA-10 cells were transiently transfected with the indicated amounts of hLHR-wt or hLHR-t682 plasmids. ${ }^{125}$ |-hCG binding (top panel) was measured during an overnight incubation at $4{ }^{\circ} \mathrm{C}$ and the hCG-induced intracellular cAMP response (bottom panel) was measured during $30 \mathrm{~min}$ with $0.3 \mathrm{nM} \mathrm{hFSH}$ as described in Materials and methods. Each point shows the average \pm S.E.M. of three to five independent transfections.

receptor density and/or changes in the functional properties, or the levels of $\mathrm{G}$ proteins or adenylyl cyclase. A number of experimental strategies using during the past three decades, however, have clearly documented that gonadotropin-induced changes in cAMP accumulation are not due to changes in the levels or the functional properties of $\mathrm{G}$ proteins or adenylyl cyclase. When cells expressing the endogenous or transfected gonadotropin receptors are exposed to gonadotropins, the subsequent loss of the gonadotropininduced cAMP response is in fact specific to the homologous hormone as documented by the finding that 

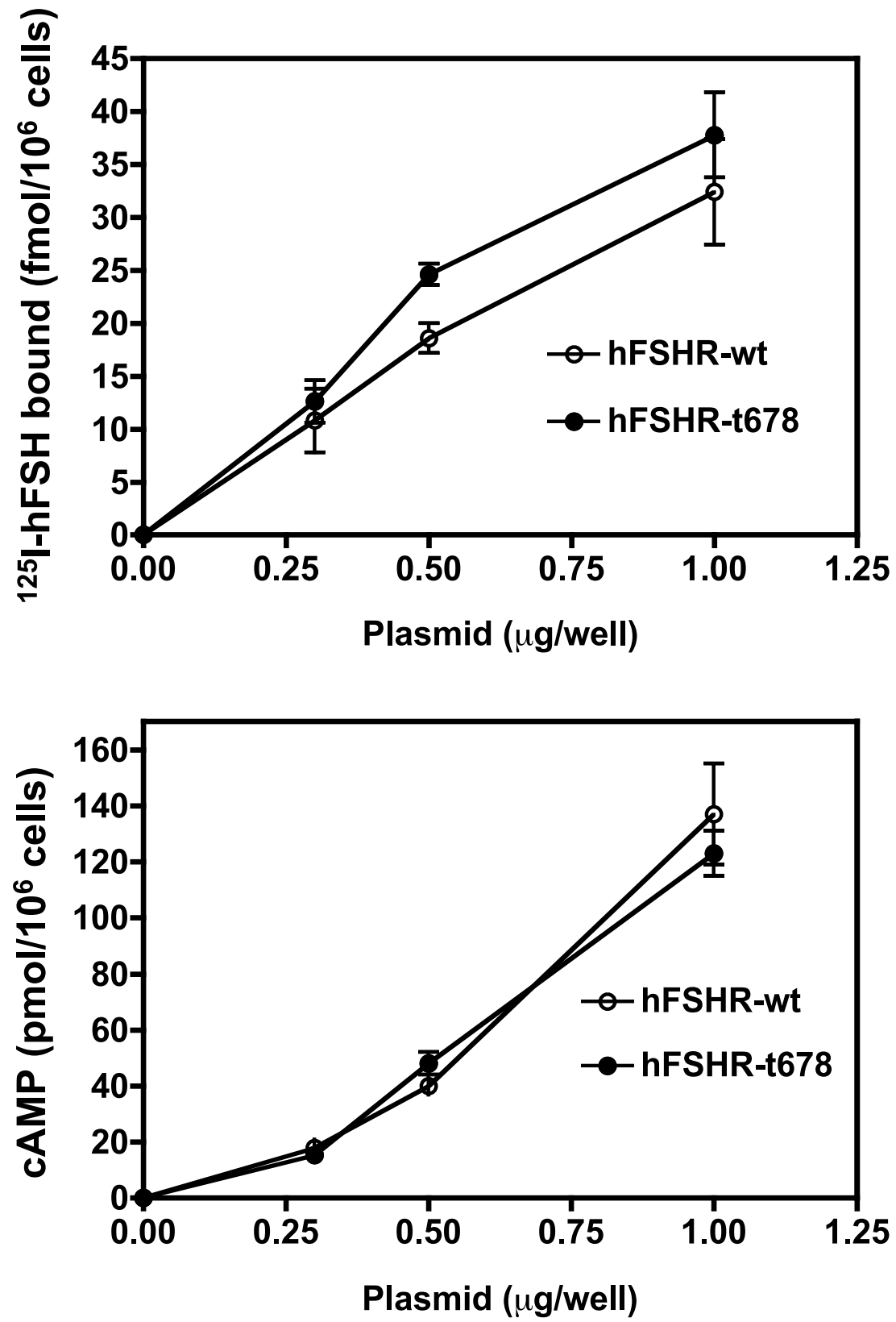

Figure 7 The hFSH-induced cAMP response is proportional to FSHR density in KK-1 cells transfected with the hFSHR-wt or hFSHR-t678. KK-1 cells were transiently transfected with the indicated amounts of hFSHR-wt or hFSHR-t678 plasmids.

125/-hFSH binding (top panel) was measured during an overnight incubation at $4{ }^{\circ} \mathrm{C}$ and the hFSH-induced intracellular cAMP response (bottom panel) was measured during $30 \mathrm{~min}$ with $0.3 \mathrm{nM} \mathrm{hFSH}$ as described in Materials and methods. Each point shows the average \pm S.E.M. of three to five independent transfections.

the cAMP responses of gonadotropin-treated cells to other stimuli such as cholera toxin or forskolin remain unchanged (Conti et al. 1977, Catt et al. 1980, Dufau et al. 1980, Darbon et al. 1984, Pereira et al. 1988, Hafez \& Ascoli 1990, Sánchez-Yagüe et al. 1993, Ascoli 1996,
1997). To ensure that receptor density is indeed a limiting factor in cellular responsiveness, we transfected MA-10 or KK-1 cells with different amounts of the hLHR and hFSHR constructs used here and we tested their ability to respond to hCG or hFSH 
respectively with an increase in cAMP accumulation. The experiments presented in Figs 6 and 7 show that there is a clear dependency of gonadotropin-induced cAMP responsiveness on receptor density.

With regards to the hCG-induced progesterone response in MA-10 cells it is already known that this response is limited not only by the density of LHR but also by the availability of cholesterol (Freeman \& Ascoli 1981, 1982). Although the experiments presented here were done under conditions where cholesterol can become depleted (Fig. 3) this depletion should not affect the interpretation of the data presented because we have previously shown that the steroidogenic response of these cells to hGG is limited by the density of receptors even when an appropriate source of exogenous cholesterol is present (Freeman \& Ascoli 1982). Lastly, when MA-10 cells are transfected with the hLHR (as done herein) there is a strong, positive correlation between the hCG-induced progesterone response and the density of receptors expressed (Hirakawa et al. 2002).

Therefore the hCG-induced loss of cAMP and progesterone responses detected in MA-10 cells (Figs 2 and 3) and the hFSH-induced loss of cAMP response detected in KK-1 cells (Fig. 5) are most likely due to the hCG- and hFSH-induced changes in the density of gonadotropin receptors (Figs 1 and 4).

\section{Discussion}

The potential involvement of the different fate of the internalized hormone receptor complexes and the differential loss of cell surface receptors on the initiation, termination or desensitization of cellular responses is not fully understood. With regards to the initiation of cellular responses, it appears that some signal transduction events generated by $\mathrm{G}$ protein-coupled receptors originate at the cell surface whereas others are generated from an endosomal compartment (Luttrell \& Lefkowitz 2002, Sorkin \& von Zastrow 2002). In the case of the mLHR, we showed a number of years ago that cAMP accumulation is a result of signals that are generated at the plasma membrane because this response stops upon removal of the surface-bound hCG from MA-10 cells even after a substantial proportion of the hormone receptor has been internalized (Segaloff \& Ascoli 1981). Therefore, in this case, the internalization of the receptor-bound hormone appears to be involved in the termination of cAMP responses. Since cAMP accumulation is essential for steroid synthesis (Pereira et al. 1987, Wang \& Ascoli 1990, Swinnen et al. 1991) and for the activation of the ERK1/2 pathway (Hirakawa \& Ascoli $2003 b$ ), one can safely assume that the activation of these downstream pathways would also stop upon removal of the surface-bound hCG. This has been formally shown only for steroid synthesis, however (Segaloff \& Ascoli 1981).

Here we have examined the importance of the post-endocytotic fate of the internalized hLHR and hFSHR on the process of receptor down-regulation and the desensitization of gonadotropin responses using the wild-type and mutant forms of the hLHR and the hFSHR expressed in MA-10 and KK-1 cells respectively. The mutants of the hLHR and hFSHR used were chosen because they are routed mostly to a lysosomal degradation pathway whereas their wild-type counterparts are recycled back to the membrane. We have shown that agonist stimulation of cells expressing the mutant gonadotropin receptors results in a more pronounced loss of cell surface receptors and agonist responses than agonist stimulation of cells expressing the wild-type receptors. We conclude, therefore, that receptor recycling promotes the maintenance of gonadotropin receptors at the cell surface, thus preserving hormonal responsiveness even under continuous hormonal stimulation. Receptor degradation, on the other hand, promotes the loss of cell surface receptors and hormonal responsiveness under continuous hormonal stimulation.

Whereas the post-endocytotic fate of the FSHR from humans and rodents is the same (Krishnamurthy et al. 2003), the hLHR recycles more efficiently than the rodent LHR (Ascoli 1984, Kishi \& Ascoli 2000, Kishi et al. 2001, Galet et al. 2003, 2004, Hirakawa et al. 2003). One must wonder then whether there is an evolutionary advantage to this change in the properties of the LHR. We speculate that the more efficient recycling of the hLHR is important in human physiology because it promotes the maintenance of hormonal responsiveness in the maternal luteal cells and the fetal Leydig cells during pregnancy when hCG levels are high.

\section{Acknowledgements}

This work was supported by grants from the National Cancer Institute (CA-40629) and the National Institute of Child Health and Human Development (HD-28962). The authors declare that there is no conflict of interest that would prejudice the impartiality of this scientific work.

\section{References}

Ascoli M 1981 Characterization of several clonal lines of cultured Leydig tumor cells: gonadotropin receptors and steroidogenic responses. Endocrinology 108 88-95.

Ascoli M 1982 Internalization and degradation of receptor-bound human choriogonadotropin in Leydig tumor cells. Fate of the hormone subunits. Fournal of Biological Chemistry 257 13306-13311. 
Ascoli M 1984 Lysosomal accumulation of the hormone-receptor complex during receptor-mediated endocytosis of human choriogonadotropin. Fournal of Cell Biology 99 1242-1250.

Ascoli M 1996 Functional consequences of the phosphorylation of the gonadotropin receptors. Biochemical Pharmacology 52 $1647-1655$.

Ascoli M 1997 Molecular basis of the regulation of the lutropin/choriogonadotropin (LH/CG) receptor. Biochemical Society Transactions 25 1021-1026.

Ascoli M \& Puett D 1978 Gonadotropin binding and stimulation of steroidogenesis in Leydig tumor cells. PNAS 75 99-102.

Baratti-Elbaz C, Chinea N, Lahuna O, Loosfelt H, Pichon C \& Milgrom E 1999 Internalization and recycling pathways of the thyrotropin receptor. Molecular Endocrinology 13 1751-1765.

Beau I, Misrahi M, Gross B, Vannier B, Loosfelt H, Vu Hai MT, Pichon C \& Milgrom E 1997 Basolateral localization and transcytosis of gonadotropin and thyrotropin receptors expressed in Madin-Darby canine kidney cells. Fournal of Biological Chemistry 272 5241-5248.

Beau I, Groyer-Picard M-T, Le Bivic A, Vannier B, Loosfelt H, Milgrom E \& Misrahi M 1998 The basolateral localization signal of the follicle-stimulating hormone receptor. Fournal of Biological Chemistry 273 18610-18616.

Catt KJ, Harwood JP, Aguilera G \& Dufau ML 1979 Hormonal regulation of peptide receptors and target cell responses. Nature $280109-116$

Catt KJ, Harwood JP, Clayton RN, Davies TF, Chan V, Katikineni M, Nozu K \& Dufau ML 1980 Regulation of peptide hormone receptors and gonadal steroidogenesis. Recent Progress in Hormone Research 36 557-622.

Conti M, Harwood JP, Dufau ML \& Catt KJ 1977 Effect of gonadotropin-induced receptor regulation on biological responses of isolated rat luteal cells. Fournal of Biological Chemistry 252 8869-8874.

Darbon J-M, Knecht M, Ranta T, Dufau ML \& Catt KJ 1984 Hormonal regulation of cyclic AMP-dependent protein kinase in cultured ovarian granulosa cells; effects of follicle-stimulating hormone and gonadotropin-releasing hormone. Fournal of Biological Chemistry 259 14778-14782.

Dufau ML, Baukal AJ \& Catt KJ 1980 Hormone-induced guanyl nucleotide binding and activation of adenylate cyclase in the Leydig cell. PNAS 77 5837-5841.

Ekstrom RC \& Hunzicker-Dunn M 1989 Homologous desensitization of ovarian luteinizing hormone/human chorionic gonadotropin-responsive adenylyl cyclase is dependent upon GTP. Endocrinology 124 956-963.

Freeman DA \& Ascoli M 1981 Desensitization to gonadotropins in cultured Leydig tumor cells involves loss of gonadotropin receptors and decreased capacity for steroidogenesis. PNAS $\mathbf{7 8}$ 6309-6313.

Freeman DA \& Ascoli M 1982 Desensitization of steroidogenesis in cultured Leydig tumor cells: role of cholesterol. PNAS $\mathbf{7 9}$ $7796-7800$.

Galet C, Min L, Narayanan R, Kishi M, Weigel NL \& Ascoli M 2003 Identification of a transferable two amino acid motif (GT) present in the C-terminal tail of the human lutropin receptor that redirects internalized $\mathrm{G}$ protein-coupled receptors from a degradation to a recycling pathway. Molecular Endocrinology 17 $411-422$.

Galet C, Hirakawa T \& Ascoli M 2004 The postendocytotic trafficking of the hLHR is mediated by a transferable motif consisting of the C-terminal cysteine and an upstream leucine. Molecular Endocrinology 18434446.

Ghinea N, Vuhai MT, Groyer-Picard M-T, Houllier A, Schoë vaërt D \& Milgrom E 1992 Pathways of internalization of the hCG/LH receptor: immunoelectron microscopic studies in Leydig cells and transfected L cells. Fournal of Cell Biology 118 1347-1358.
Hafez MM \& Ascoli M 1990 Epidermal growth factor desensitizes the gonadotropin-responsive adenylyl cyclase in membranes isolated from MA-10 Leydig tumor cells and luteinized rat ovaries. Endocrinology $127394-402$.

Hirakawa T \& Ascoli M 2003a A constitutively active somatic mutation of the human lutropin receptor found in Leydig cell tumors activates the same families of $\mathrm{G}$ proteins as germ line mutations associated with Leydig cell hyperplasia. Endocrinology $1443872-3878$.

Hirakawa T \& Ascoli M 2003b The lutropin/choriogonadotropin receptor (LHR)-induced phosphorylation of the extracellular signal regulated kinases (ERKs) in Leydig cells is mediated by a protein kinase A-dependent activation of Ras. Molecular Endocrinology 17 2189-2200.

Hirakawa T, Galet C \& Ascoli M 2002 MA-10 cells transfected with the human lutropin/choriogonadotropin receptor (hLHR). A novel experimental paradigm to study the functional properties of the hLHR. Endocrinology 143 1026-1035.

Hirakawa T, Galet C, Kishi M \& Ascoli M 2003 GIPC binds to the human lutropin receptor (LHR) through an unusual PDZ domain binding motif and it regulates the sorting of the internalized human choriogonadotropin (hCG) and the density of cell surface LHR. Journal of Biological Chemistry 278 49348-49357.

Hunzicker-Dunn M, Gurevich VV, Casanova JE \& Mukherjee S 2002 ARF6: a newly appreciated player in G protein-coupled receptor desensitization. FEBS Letters 521 3-8.

Kishi M \& Ascoli M 2000 The G-terminal tail of the rat lutropin/choriogonadotropin receptor independently modulates hCG-induced internalization of the cell surface receptor and the lysosomal targeting of the internalized hCG-receptor complex. Molecular Endocrinology 14 926-936.

Kishi M, Liu X, Hirakawa T, Reczek D, Bretscher A \& Ascoli M 2001 Identification of two distinct structural motifs that, when added to the $\mathrm{C}$-terminal tail of the rat lutropin receptor, redirect the internalized hormone-receptor complex from a degradation to a recycling pathway. Molecular Endocrinology 15 1624-1635.

Krishnamurthy H, Kishi H, Shi M, Galet C, Bhaskaran RS, Hirakawa T \& Ascoli M 2003 Post-endocytotic trafficking of the FSH/FSH receptor complex. Molecular Endocrinology 17 2162-2176.

Lamm MLG \& Hunzicker-Dunn M 1994

Phosphorylation-independent desensitization of the luteinizing hormone/chorionic gonadotropin receptor in porcine follicular membranes. Molecular Endocrinology 8 1537-1546.

Luttrell LM \& Lefkowitz RJ 2002 The role of $\beta$-arrestins in the termination and transduction of G-protein-coupled receptor signals. Fournal of Cell Science 115 455-465.

Mendelson C, Dufau M \& Catt K 1975 Gonadotropin binding and stimulation of cyclic adenosine $3^{\prime}: 5^{\prime}$-monosphosphate and testosterone production in isolated Leydig cells. Fournal of Biological Chemistry $2508812-8823$.

Min L \& Ascoli M 2000 Effect of activating and inactivating mutations on the phosphorylation and trafficking of the human lutropin/choriogonadotropin receptor. Molecular Endocrinology 14 1797-1810.

Mukherjee S, Palczewski K, Gurevich V, Benovic JL, Banga JP \& Hunzicker-Dunn M 1999 A direct role for arrestins in desensitization of the luteinizing hormone/choriogonadotropin receptor in porcine ovarian follicular membranes. PNAS 96 493-498.

Nozu K, Zawistowich L, Catt KJ \& Dufau ML 1981 Gonadotropin-induced receptor regulation and steroidogenic lesions in cultured leydig cells. Fournal of Biological Chemistry 256 12875-12882.

Pereira ME, Segaloff DL, Ascoli M \& Eckstein F 1987 Inhibition of choriogonadotropin-activated steroidogenesis in cultured Leydig tumor cells by the $\mathrm{Rp}$ diastereoisomer of adenosine $3^{\prime}, 5^{\prime}$-cyclic phosphorothioate. Fournal of Biological Chemistry 262 6093-6100. 
Pereira ME, Segaloff DL \& Ascoli M 1988 Inhibition of gonadotropin-responsive adenylate cyclase in MA-10 Leydig tumor cells by epidermal growth factor. Fournal of Biological Chemistry 263 9761-9766.

Quinn PG, Dombrausky LJ, Chen Y-DI \& Payne AH 1981 Serum lipoproteins increase testosterone production in hCG-desensitized Leydig cells. Endocrinology 109 1790-1792.

Rahman NA \& Huhtaniemi IT 2001 Ovarian tumorogenesis in mice transgenic for murine inhibin $\alpha$ subunit promoter-driven simian virus $40 \mathrm{~T}$-antigen: ontogeny, functional characteristics, and endocrine effects. Biology of Reproduction 64 1122-1130.

Sánchez-Yagüe J, Hipkin RW \& Ascoli M 1993 Biochemical properties of the agonist-induced desensitization of the FSH- and LH/CG-responsive adenylyl cyclase in cells expressing the recombinant gonadotropin receptors. Endocrinology 132 1007-1016.

Segaloff DL \& Ascoli M 1981 Removal of surface-bound human choriogonadotropin results in cessation of hormonal responses in cultured Leydig tumor cells. Fournal of Biological Chemistry 256 $11420-11423$.

Sorkin A \& von Zastrow M 2002 Signal transduction and endocytosis: close encounters of many kinds. Nature Reviewes Molecular and Cellular Biology 3 600-614.

Swinnen JV, D'Souza B, Conti M \& Ascoli M 1991 Attenuation of cAMP-mediated responses in MA-10 Leydig tumor cells by genetic manipulation of a cAMP-phosphodiesterase. Fournal of Biological Chemistry 266 14383-14389.

Wang H \& Ascoli M 1990 Reduced gonadotropin responses in a novel clonal strain of Leydig tumor cells established by transfection of MA-10 cells with a mutant gene of the type I regulatory subunit of the cAMP-dependent protein kinase. Molecular Endocrinology 4 80-90.

Wang H, Segaloff DL \& Ascoli M 1991 Lutropin/choriogonadotropin down-regulates its receptor by both receptor mediated endocytosis and a cAMP-dependent reduction in receptor mRNA. Fournal of Biological Chemistry 266 780-785.

Wang H, Nelson S, Ascoli M \& Segaloff DL 1992 The 5' flanking region of the rat lutropin/choriogonadotropin receptor gene confers Leydig cell expression and negative regulation of gene transcription by cAMP. Molecular Endocrinology 6 320-326.

Wang Z, Liu X \& Ascoli M 1997 Phosphorylation of the lutropin/choriogonadotropin receptor facilitates uncoupling of the receptor from adenylyl cyclase and endocytosis of the bound hormone. Molecular Endocrinology 11 183-192.

Received 13 December 2004

Accepted 19 December 2004

Made available online as an Accepted Preprint 5 January 2005 